\title{
How to Feed 311 Million of Indonesian People by 2050? Advancing Local Food Adaptation and Food Security Policy
}

\author{
Marlisa Ayu Trisia ${ }^{* 1}$, Katsuya Osozawa ${ }^{2}$ and Hu Bai ${ }^{2}$ \\ ${ }^{1}$ The United Graduate School of Agricultural Science, Ehime University, 3-5-7 Tarumi, \\ Matsuyama, Ehime 790-8566, Japan \\ ${ }^{2}$ Department of Bioresources and Environmental Policy, Faculty of Agriculture, Ehime University, \\ 3-5-7 Tarumi, Matsuyama, Ehime 790-8566, Japan \\ Email: marlisaatrisia@yahoo.com*
}

\begin{abstract}
During decades, rice production in Indonesia has continuously increased. However, the increase in food consumption is faster than the rate of production. The population growth in Indonesia is projected to grow by $24.5 \%$ over the next four decades, from 250 million in 2015 to 311 million in 2050. In addition, climate change impacts would also exacerbate food supply and endanger sustainable food production. If the food needs for the population cannot be met, Indonesia will become a food insecurity country. On the other hand, Indonesia has a great potential food supply from a local resource that can be developed as the basis for food security in the long-term period. However, those local food resources are not considered the main staple food although their production is not significantly influenced by climate. The advancing potency of local food adaptation can create climate-resilient agriculture to proceed national food security. In addition, effective governance is needed to implement policies which promote food availability, food accessibility and individual food utilization based on local resources.
\end{abstract}

Keywords: Adaptation, food security, local food, policy

\section{INTRODUCTION}

Food security happens when people have physical and economic access to sufficient, safe, and nutritious food to support their dietary needs and enable an active and healthy life (FAO 2008). However, greater challenges await in feeding more than 9 billion of the world population in 2050 (Lal 2013) when the global food production is expected to increase by $60 \%$ (FAO 2012). The increasing population will be followed by increasing of food consumption, but in the same time, the competition for land, water and energy will affect the food production (Lal, 2013). The climate change effects and extreme climate events are also leading food insecurity (FAO, 2008). An increasing of local temperature of $2{ }^{\circ} \mathrm{C}$ is projected to negatively impact yields for major crops such as wheat, rice, and maize (Porter et al. 2014).

Indonesia is the third largest emitters of greenhouse gasses in the world with a total of 3,014 MtCO2e after the United States and China (Sari et al. 2007) and the fourth biggest population in the world (Sulaiman 2010).
Mostly Indonesian population consume rice as the main staple food, but the production has been influenced by climate change hazards such as flood and drought (Iizumi, Yokozawa, and Nishimori 2011). A month's delay in the onset of the wet season due to climate change can decrease rice production by as much as $65 \%$ in West Java and Central Java (Naylor et al. 2007). Moreover, the rice paddy production has been decreased in Bali by $20 \%$ in the last 20 years because of climate change (Takama et al. 2014). The research projection in 2050 also showed the area of paddy fields will reduce in Java-Bali (182,556 ha) as well as in Sulawesi (78,701 ha), Kalimantan (25,372 ha), Sumatra (3,170 ha) and Lombok (2,123 ha) (Triastuti et al. 2009). Therefore, full dependency on rice will put people to food insecurity because of future climate change.

Indonesia has a great potential food supply from a local resource that are more tolerate of variable climate change such as sago palm (Bantacut 2014; Girsang 2014) and tubers such as cassava (Jarvis et al. 2012) and sweet potato. Nevertheless, the minimum 
attention has been given because they are not considered as the main staple food. This paper discussed the Indonesian food security system and commitment from government to increase national food security through local food adaptation.

\section{METHODOLOGY}

This research was conducted in Jakarta, Indonesia under Ministry of Agriculture (MoA) and Ministry of National Development Planning (BAPPENAS) for a semi-structured interview with total 20 key respondents. Policy database from FAOLEX and legal documents were also reviewed to complete the study.

\section{RESULT AND DISCUSSION}

\subsection{Rice situation in Indonesia}

Based on FAO STAT, the trend for per capita rice production increased from 1970 until 1990, decreased in 2000 and then increased again in 2010 (Table 1). However, as a rice producing country, Indonesia is also the biggest importer country in the world (Widyanti et al. 2014). The government has developed agricultural revolution since the 1960s in order to achieve rice production target and self-sufficiency in the 1984 (Mulyani and Las 2008). However, in 1997-1998, the government published Ministerial Regulation $439 / 1998$ to give $0 \%$ tax for rice import due to the economic crisis (Metaragakusuma 2014) and since then, the government imposed an import policy with open and close systems regarding seasonal cycle (Saifullah 2010). The rice policy was also integrated into part of the national transmigration program until the 1990s and continued through the "rice for the poor/RASKIN" policy in 2000s with a subsidy from the government which provides rice in low price for rural people (Girsang 2014).

The rice policies caused a great deal of change in Indonesian food pattern into single staple food that increased rice consumption from 53.3\% in 1945 into $88.1 \%$ in 1999 and 78.04\% by 2010 (Food Security Agency 2015). The high dependency of rice has also weakened food diversification. In the eastern part of Indonesia, for example, the people used to eat sago, as well as sweet potatoes and cassava for staple food; maize in East Java and some part in Nusa Tenggara Barat and cassava in East Java and Central Java. However, they have become accustomed to eating rice in the last few decades because of "rice policy". It also gave minimum implications on non-ricebased foods research investments (Widyanti et al. 2014) and reduced other local foods market (Hariyadi 2013).

Hence, the high dependency with single food (i.e. rice) can be vulnerable for national food security of Indonesia especially when the population is also growing faster. The population growth in Indonesia is projected to grow by $24.5 \%$ over the next four decades, from 250 million in 2015 to 311 million in 2050 (United nations Population Division 2015) that give a greater challenge to fulfill food needs especially when the support for local food resources is minimum.

Table 1 Indonesian population and rice production from 1970-2010

\begin{tabular}{|c|c|c|c|}
\hline Year & $\begin{array}{c}\text { Total rice } \\
\text { production } \\
\left(10^{6} \mathrm{~kg}\right)\end{array}$ & $\begin{array}{c}\text { Population } \\
\left(10^{6}\right)\end{array}$ & $\begin{array}{c}\text { Per capita } \\
\text { production } \\
(\mathrm{kg})\end{array}$ \\
\hline 1970 & 19331 & 115 & 168 \\
\hline 1980 & 29652 & 147 & 202 \\
\hline 1990 & 45726 & 181 & 253 \\
\hline 2000 & 51898 & 212 & 245 \\
\hline 2010 & 66469 & 242 & 275 \\
\hline
\end{tabular}

Source: FAO STAT (2015)

\subsection{Indonesia's food security commitment}

A Food Security and Vulnerability Atlas of Indonesia report mentioned about 25 million people are vulnerable to food security due to the high poverty level, no access by vehicle, no clean water, a high ratio cereal requirement and high underweight among under-five years children (World Food Programme 2009). Along with the increasing of domestic rice production, the government implemented several food security policies related to food diversification and climate change (Table 2). Indonesia's national law 7/1996 and National Action Plan for Climate Change Adaptation (RAN-API) in 2014 acted as an umbrella framework for food security and recognized that climate change is a trigger of the food crisis. It provides food security fundamental and coordination between ministries to tackle climate change issues, but there is a question on implementation of the policies. Following with those policies, the government published 
regulation 68/2002. Despite having been created in 2002, the policy does not have a clear vision in term of planning, implementing, budgeting and evaluating at the local level. In 2010, Ministerial Regulation 65/2010 was published as a guide for a minimum standard of operational for food security at the local level together with Law 18/2012 that offers a framework of food independence and food sovereignty. However, there is a lack of reliable political will in that policies. It is because mostly the local food resources are not treated as a priority crop to develop for the purpose of economic and food security. The existence of local food also depends on the socio-cultural environment in that region, therefore, local government should have enough knowledge to identify local food and implement this regulation.

Table 2 Indonesian national policies on food security

\begin{tabular}{|c|c|}
\hline Policies & Statement \\
\hline Law 7/1996: Food & $\begin{array}{l}\text { The goal of national } \\
\text { food systems is to } \\
\text { achieve food security } \\
\text { through food } \\
\text { availability, food } \\
\text { supplies and } \\
\text { affordable for } \\
\text { consumer }\end{array}$ \\
\hline $\begin{array}{l}\text { Government } \\
\text { regulation } 68 / 2002 \text { : } \\
\text { Food security }\end{array}$ & $\begin{array}{l}\text { Outline on food } \\
\text { security, national } \\
\text { food supply, food } \\
\text { diversification, } \\
\text { disease prevention, } \\
\text { and food control }\end{array}$ \\
\hline $\begin{array}{l}\text { Presidential Decree } \\
\text { 22/2009: } \\
\text { Acceleration of } \\
\text { food consumption } \\
\text { diversification } \\
\text { based on local } \\
\text { resources }\end{array}$ & $\begin{array}{l}\text { Recommendation for } \\
\text { local government to } \\
\text { revive local food as } \\
\text { an alternative food } \\
\text { diversification }\end{array}$ \\
\hline $\begin{array}{l}\text { Ministerial } \\
\text { Regulation } \\
\text { 43/2009: } \\
\text { Acceleration of } \\
\text { diversification } \\
\text { movement based on } \\
\text { local resources }\end{array}$ & $\begin{array}{l}36 \text { agricultural } \\
\text { commodities were } \\
\text { selected to be } \\
\text { developed with } \\
\text { support from state } \\
\text { budget (APBN) }\end{array}$ \\
\hline $\begin{array}{l}\text { Ministerial } \\
\text { regulation 65/2010: }\end{array}$ & $\begin{array}{l}\text { Local government is } \\
\text { responsible for food }\end{array}$ \\
\hline
\end{tabular}

\begin{tabular}{|l|l|}
\hline \multicolumn{1}{|c|}{ Policies } & \multicolumn{1}{c|}{ Statement } \\
\hline $\begin{array}{l}\text { Minimum standard } \\
\text { of operational for } \\
\text { food security in } \\
\text { provincial and } \\
\text { district }\end{array}$ & $\begin{array}{l}\text { security and } \\
\text { encourage } \\
\text { community to } \\
\text { participate through } \\
\text { (a) provide } \\
\text { information and } \\
\text { education; (b) } \\
\text { increase the } \\
\text { motivation of people; } \\
\text { (c) support the } \\
\text { implementation of } \\
\text { food security system }\end{array}$ \\
\hline $\begin{array}{l}\text { Law 18/2012: Food } \\
\text { policy }\end{array}$ & $\begin{array}{l}\text { National } \\
\text { government, local } \\
\text { government, and } \\
\text { community need to } \\
\text { develop potential } \\
\text { food production to } \\
\text { decrease food } \\
\text { insecurity }\end{array}$ \\
\hline $\begin{array}{l}\text { National Action for } \\
\text { Climate Change } \\
\text { Adaptation (RAN- } \\
\text { API) in 2014 }\end{array}$ & $\begin{array}{l}\text { Nocument is a } \\
\text { framework of climate } \\
\text { change adaptation in } \\
\text { Indonesia. One of the } \\
\text { targets focuses on } \\
\text { food security for } \\
\text { economic resilience }\end{array}$ \\
\hline nutrition & $\begin{array}{l}\text { Climate change is a } \\
\text { trigger of food crisis, } \\
\text { therefore, it is } \\
\text { important to have } \\
\text { food reserves in the } \\
\text { local area }\end{array}$ \\
\hline Rogulation & Food
\end{tabular}

Compiled from FAOLEX and interview

In 2009, the government focused on localbased food diversification program through Presidential Decree 22/2009 and Ministerial Regulation 43/2009 to revive 36 local commodities as an alternative food diversification for local self-sufficiency with support from the state budget (APBN). It is simply assumed that finances will be covered by APBN without further consideration of whether and how this will be connected to local budget (APBD). Although the commitment to support food security and promote local-based-food diversification has been recognized, but in reality the commitment still has minimum impact and has not sustainable. The diversification program started in 2012 through Local Food 
Diversification Program (MP3L) (Table 3) with total amount IDR 18.9 billion from 2012to 2015. The total budget from 2012 to 2014 for this program was only $0.57 \%$ from the total state budget of Food Security AgencyMinistry of Agriculture, considering just small budget to promote food diversification. Food diversification program also failed in Central Java because of the high dependency to rice (Widyanti, Sunaryo, and Kumalasari 2014). It proves that public perception on rice addiction is cultural and can be a barrier to food diversification program along with the minimum priority and support for local food industry and food technology.

The Indonesian RAN-API on climate change adaptation, and Government Regulation 17/2015 on food security and nutrition can be seen as a sprout of a climate change approach for food security. Nonetheless, those policies still contain at least two weaknesses. First, RAN-API is only a framework, therefore there is no solid commitment from all ministries to promote food security for climate change adaptation purpose. Minimum interest on local food adaptation approach, that can create climateresilient agricultural, may contribute to national insecurity. Second, it does not completely outline the implementation of local government and community to develop potential food production to decrease food crisis because of climate change, disaster, and other issues and provide food reserves in the local area.

Table 3 Local Food Diversification Program (MP3L) budget from 2012-2015

\begin{tabular}{|l|c|c|c|c|}
\hline \multirow{2}{*}{ Crops } & \multicolumn{4}{|c|}{ Budget (IDR million) } \\
\cline { 2 - 5 } & $\mathbf{2 0 1 2}$ & $\mathbf{2 0 1 3}$ & $\mathbf{2 0 1 4}$ & $\mathbf{2 0 1 5}$ \\
\hline Sago & 1,050 & 350 & - & 3,850 \\
\hline Maize & 1,050 & 2,450 & - & 1,750 \\
\hline Cassava & 1,750 & 2,450 & 1,400 & 2,450 \\
\hline Taro & - & - & - & 350 \\
\hline Total & $\mathbf{3 , 8 5 0}$ & $\mathbf{5 , 2 5 0}$ & $\mathbf{1 , 4 0 0}$ & $\mathbf{8 , 4 0 0}$ \\
\hline
\end{tabular} Source: Interview

\subsection{Improving food independence through local food adaptation}

Since political, economic structure and socio-cultural environment are the basic determinants for food security (Verduijn 2005), then it is a necessity for Indonesia to develop its own system that suits with the local condition and available local food resources. Food independence should be done in the vertical and horizontal structure (Hariyadi 2003). Indonesian decentralization system created the legal frame conditions and transfer of responsibility and authority over natural resources from central government to the local level (McCarthy 2000). Therefore, the local government has the authority to identify local food potency and strengthen their food security. Then, this activity should be supported with a political commitment from the national level.

Indonesian government needs a strong commitment for revitalizing food program aligned with well-defined and development of local food industry. Changing the dietary behavior and mindset also plays an important role (Widyanti et al. 2014). National food system support from local resources adaptation will have strong linkage and have less dependency on single food.

\section{CONCLUSION}

Poverty, food security and disparities between regions remain a major challenge for decision makers in Indonesia. Therefore, commitment and synergy between national and local government are needed. Potential resources such as environment, technology, and human resources can support local foodbased industry in order to build solid food security for facing challenges in 2050.

\section{REFERENCES}

Bantacut, Tajuddin. 2014. Indonesian Staple Food Adaptations for Sustainability in Continuously Changing Climates. Journal of Environment and Earth Science, 4(21): 202-16.

FAO. 2008. Climate Change and Food Security: A Framework Document. Rome, Italy: FAO.

. 2012. The State of Food Insecurity in the World 2012. Rome, Italy: FAO.

Food Security Agency. 2012. Roadmap of Food Diversification 2011-2015. Jakarta.

Girsang, Wardis. 2014. Socio-Economic Factors That Have influenced the Decline of Sago Consumption in Small Islands: A Case in Rural Maluku, Indonesia. South Pacific Study, 34(2): 99-116. 
Hariyadi, Purwiyatno. 2003. Food Diversification-Regional Government and Private Initiative. Industrialization of Food Diversification-Toward Indigenous Resource-Based Food Security Meeting. Jakarta.

-2013. Beyond Food Security. (http://www.researchgate.net/publication/ 259254612_Beyond_Food_Security). Accessed on March 25, 2015.

Iizumi, Toshichika, Masayuki Yokozawa, and Motoki Nishimori. 2011. Probabilistic Evaluation of Climate Change Impacts on Paddy Rice Productivity in Japan. Climatic Change, 107(3-4): 391-415.

Jarvis, Andy, Julian Ramirez-Villegas, Beatriz Vanessa Herrera Campo, and Carlos Navarro-Racines. 2012. Is Cassava the Answer to African Climate Change Adaptation?. Tropical Plant Biology, 5(1): 9-29.

Lal, Rattan. 2013. Food Security in A Changing Climate. Ecohydrology \& Hydrobiology, 13(1): 8-21.

McCarthy, J.F. 2000. The Changing Regime: Forest Property and Reformation in Indonesia. Development and Change, 31: 91-129.

Metaragakusuma, A.P. 2014. Sago Development in South Sulawesi: Its Current Situation, New Movement and the Succession of the Sago Culture by Small Scale Farmers. Thesis. Japan: Ehime University.

Mulyani, Anny, and Irsal Las. 2008. Land Resources Potential and Optimization of Bioenergy Producing Commodities Development in Indonesia. Research and Development of Agriculture, 27(1): 3141.

Naylor, R.L., Battisti D.S. Vimont, W.P. Falcon, and M.B Burke. 2007. Assessing Risks of Climate Variability and Climate Change for Indonesian Rice Agriculture. Proceeding of the National Academic of Science, 114: 7752-57.

Porter, J.R., Xie, L., Challinor, A., Cochrane, K., Howden, S., Iqbal, M., Lobell, D., Travasso, M. 2014. Food Security and Food Production Systems. Cambridge: Cambridge University Press.
Saifullah, Agus. 2010. Indonesia's Rice Policy and Price stabilization Program: Managing Domestic Prices during the 2008 Crisis. In The Rice Crisis': Market, Policies, and Food Security. (109-22). (Editor: David Dawe). London: FAO and Earthscan.

Sari, A., Maulidya, M., Butarbutar, R., Sari, R., and Rusmantoro, W. 2007. Executive Summary: Indonesia and Climate Change, Working Paper on Current Status and Policies. Jakarta: PEACE.

Simelton, Elisabeth, Fraser, E., Termansen, Mette, Benton, Tim, Gosling, S., South, Andrew, Arnell, N., Challinor, A., Dougill, A., Forster, P. 2012. The Socioeconomics of Food Crop Production and Climate Change Vulnerability: A Global Scale Quantitative Analysis of How Grain Crops Are Sensitive to Drought. Food Security 4(2): 163-79.

Sulaiman, D. S. 2010. Lesson Learned from 2010 Indonesia Population and Housing Census.

(http://www.stat.go.jp/english/info/meeti ngs/eastasia/pdf/13pa2idn.pdf). Accessed on October 14, 2015.

Takama, Takeshi, Pudji Setyani, and Edvin Aldrian. 2014. Climate Change Vulnerability to Rice Paddy Production in Bali, Indonesia. In Handbook of Climate Change Adaptation. (1-23). Berlin: Springer.

Triastuti, U., Tedjakusuma, E., Sriyanti, Girianna, M., Darajati, W., Hernowo, B., Hidayat, Y., Prihartono, B., Simarmata, M., Azdan, M., Armawikarta, A., Hidayat, B., Mintzer, Irving. 2009. Indonesia Climate Change Sectoral Roadmap ICCSR Synthesis Report. BAPPENAS: Jakarta.

United nations Population Division. 2015. Total Population by Country. (http://www.un.org/en/development/desa/ population/). Accessed on October 14, 2015.

Verduijn, Rene. 2005. Strengthening Food Insecurity and Vulnerability Information Management in Lesotho: FIVIMS Assessment Report. FAO: Maseru. 
Widyanti, Ari, Indryati Sunaryo, and

Kumalasari, A. 2014. Reducing the Dependency on Rice As Staple Food in Indonesia - a Behavior Intervention Approach. Journal of ISSAAS, 20(1): 93103.

World Food Programme. 2009. "A Food Security and Vulnerability Atlas of Indonesia.(http://documents.wfp.org/stell ent/groups/public/documents/ena/wfp236 710.pdf). Accessed on October 12, 2015. 